ORIGINAL ARTICLE / ARTIGO ORIGINAL

\title{
Translation and cultural adaptation into Brazilian Portuguese of the Finnish Diabetes Risk Score (FINDRISC) and reliability assessment
}

\section{Tradução e alaptação transcultural para o português brasileiro do Escore Finlandês de Risco de Diabetes (FINDRISC) e avaliação da confiabilidade}

\author{
Estela Maria Barim' (D), Kátia Cristina Portero McLellan" (D), Rogério Silicani Ribeiro'II (D),

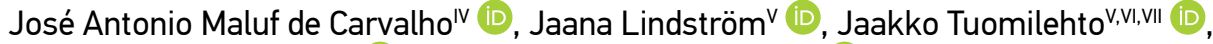 \\ José Eduardo CorrentevilI (ID, Cristiane Murta-Nascimento' (iD
}

\begin{abstract}
Introduction: The Finnish Diabetes Risk Score (FINDRISC) is a tool that was initially developed to predict the risk of developing type 2 diabetes mellitus in adults. This tool is simple, quick to apply, non-invasive, and low-cost. The aims of this study were to perform a translation and cultural adaptation of the original version of FINDRISC into Brazilian Portuguese and to assess test-retest reliability. Methodology: This work was done following the ISPOR Principles of Good Practice for the Translation and Cultural Adaptation Process for PatientReported Outcomes Measures. Once the final Brazilian Portuguese version (FINDRISC-Br) was developed, the reliability assessment was performed using a non-random sample of 83 individuals attending a primary care health center. Each participant was interviewed by trained registered dieticians on two occasions with a mean interval of 14 days. The reliability assessment was performed by analyzing the level of agreement between the test-retest responses of FINDRISC-Br using Cohen's kappa coefficient and the intraclass correlation coefficient (ICC). Results: The steps of ISPOR guidelines were consecutively followed without major problems. Regarding the reliability assessment, the questionnaire as a whole presented adequate reliability (Cohen's kappa $=0.82$, $95 \%$ CI $0.72-0.92$ and ICC $=0.94,95 \%$ CI $0.91-0.96$ ). Conclusion: FINDRISC was translated into Brazilian Portuguese and culturally adapted following standard procedures. FINDRISC-Br has thus become available for use and has potential as a screening tool in different Brazilian settings and applications.
\end{abstract}

Keywords: Diabetes mellitus. Screening. Translating. Brazil. Reproducibility of results.

\footnotetext{
'Medical School, Universidade Estadual Paulista (UNESP) - Botucatu (SP), Brazil.

"Texas Institute for Kidney and Endocrine Disorders - Lufkin (TX), United States of America.

I'Diabetes Program, Hospital Israelita Albert Einstein - São Paulo (SP), Brazil.

vViagnosis and Therapy Support Service, Beneficência Portuguesa de São Paulo - São Paulo (SP), Brazil.

veublic Health Promotion Unit, National Institute for Health and Welfare - Helsinki, Finland.

v'Department of Public Health, University of Helsinki - Helsinki, Finland.

ViDiabetes Research Group, King Abdulaziz University - Jeddah, Saudi Arabia

VIIIInstitute of Biosciences, Universidade Estadual Paulista (UNESP) - Botucatu (SP), Brazil.

Corresponding author: Estela Maria Barim. Centro de Saúde Escola Vila dos Lavradores, Universidade Estadual Paulista "Júlio de Mesquita Filho". Rua Doutor Gaspar Ricardo, 181, Vila dos Lavradores, CEP: 18609-055, Botucatu, SP, Brazil. E-mail: estela. barim@uol.com.br

Conflict of interests: none - Financial support: none.
} 
RESUMO: Introdução: O Escore Finlandês de Risco de Diabetes (FINDRISC) é um instrumento que inicialmente foi desenvolvido para predizer o risco de desenvolver diabetes mellitus tipo 2 em adultos. Esse instrumento é simples, rápido de aplicar, não invasivo e de baixo custo. Os objetivos deste estudo foram descrever o processo de tradução e adaptação transcultural do FINDRISC para o português do Brasil e avaliar a sua confiabilidade teste-reteste. Metodologia: O projeto foi conduzido de acordo com as recomendações dos Princípios de Boas Práticas para o Processo de Tradução e Adaptação Transcultural de Medidas de Resultados Relatados pelo Paciente desenvolvidas pela ISPOR. Uma vez desenvolvida a versão final em português brasileiro (FINDRISC-Br), realizou-se a avaliação da confiabilidade usando uma amostra não aleatória de 83 indivíduos atendidos em uma unidade de atenção básica. Cada participante foi entrevistado por nutricionistas registradas treinadas em duas ocasiões com intervalo médio de 14 dias. A avaliação da confiabilidade foi realizada por meio da análise do nível de concordância entre as respostas do teste-reteste, utilizando-se o coeficiente kappa de Cohen e o coeficiente de correlação intraclasse (CCI). Resultados: As etapas das diretrizes da ISPOR foram seguidas consecutivamente sem maiores problemas. Em relação à avaliação da confiabilidade do teste-reteste, o questionário como um todo apresentou confiabilidade adequada (kappa de Cohen = 0,82; IC95\% 0,72 - 0,92 e CCI = 0,94; IC95\% 0,91 - 0,96). Conclusão: O FINDRISC foi traduzido e adaptado transculturalmente para o português do Brasil seguindo procedimentos padronizados. O FINDRISC-Br já está disponível para uso e tem potencial para ser usado como ferramenta de rastreamento em diferentes cenários brasileiros.

Palavras-chave: Diabetes mellitus. Rastreamento. Tradução. Brasil. Reprodutibilidade dos testes.

\section{INTRODUCTION}

The Finnish Diabetes Risk Score (FINDRISC) is a tool developed by Finnish researchers to predict the risk of developing type 2 diabetes mellitus (T2DM) within ten years among adults aged 35-64 years ${ }^{1-3}$. FINDRISC is one of the most commonly used questionnaires to identify people at high risk for T2DM in different populations of the world ${ }^{4.8}$ and has several advantages over other risk scores ${ }^{9,10}$. Other than predicting the risk of T2DM, it has also been shown to detect undiagnosed $\mathrm{T} 2 \mathrm{DM}^{11,12}$ and hepatic steatosis ${ }^{13}$ and to predict drug-treated hypertension, cardiovascular events, and total mortality ${ }^{14,15}$. FINDRISC is composed of eight parameters: age, body mass index, waist circumference, physical activity, diet (fruit, vegetable, and berry consumption), personal history of antihypertensive drug use, personal history of hyperglycemia (including previous gestational diabetes), and family history of diabetes. Each response is scored according to associated risk, with a final sum score range of 0-26 points ${ }^{1,2}$.

The FINDRISC questionnaire has been applied previously in some studies in Brazil 13,16-19. However, they used a simple translation of the original tool, not following standard procedures. Therefore, we decided to produce a new Brazilian Portuguese version of FINDRISC in accordance with standard procedures, intending to contribute to an increasing use of more reliable tools. In this paper, we report the process of translation and cross-cultural adaptation of the original version of FINDRISC into Brazilian Portuguese, and its test-retest reliability assessment. 


\section{METHODOLOGY}

\section{SETTING AND SUBJECTS}

This study took place in a primary care health center managed by the Botucatu Medical School of Universidade Estadual Paulista "Júlio de Mesquita Filho" (UNESP). This center serves a population of more than 40,000 inhabitants, corresponding to $30 \%$ of the population in Botucatu, State of São Paulo, Brazil. Individuals aged 18 years or older were invited to participate in the study as they were waiting for an appointment at the primary care health center. Those with cognitive problems and/or with a previous diagnosis of DM were not included. This study was performed between July and September of 2017. Interviews were conducted in two stages, from Monday to Friday, in the mornings and afternoons, with an average of 6 to 7 subjects interviewed sequentially. The first stage (test) involved the following procedures: inviting subjects to participate in the study; assessing the eligibility criteria; explaining to subjects the two stages of the study; reading and signing by the subjects of the informed consent form; anthropometric measurements; applying the questionnaire; and scheduling the second interview. The second stage (retest) involved: anthropometric measurements and application of the questionnaire.

The interviews were performed in a consulting room by three registered dieticians, who also performed the anthropometric measurements. Bodyweight and height were measured with minimal clothing and bare feet, using a scale with a coupled stadiometer (MIC-200PPA, Micheletti, São Paulo, Brazil). Standing height was measured with the head positioned in the Frankfurt plane. Waist circumference was measured using a measuring tape at the level of the navel. Body mass index (BMI) was calculated as body weight in kilograms divided body height in meters squared.

The interviewers were trained before the application of the questionnaire. The training program consisted of two sessions. In the first session, the questionnaire was read, the interviewers were provided with an overview of the anthropometric measurements, and doubts were clarified. The second session was to test and train the interviewers. In this session, the interviewers conducted ten mock interviews, while the instructor (E. M. B.) provided corrective feedback.

The research protocol was submitted to and approved by the Human Research Ethics Committee of the Botucatu Medical School of UNESP (approval number 1,357,626) and written informed consent was obtained from all subjects.

\section{TRANSLATION AND CULTURAL ADAPTATION}

The translation and cultural adaptation process were conducted following the recommended principles of good practice for the translation and cultural adaptation for patient-reported 
outcomes measures developed by the International Society for Pharmacoeconomics and Outcomes Research (ISPOR) Task Force ${ }^{20}$. According to the ISPOR guidelines the process consists of ten steps:

1. Preparation;

2. Forward translation;

3. Reconciliation;

4. Back translation;

5. Back translation review;

6. Harmonization;

7. Cognitive Debriefing;

8. Review of cognitive debriefing results and finalization;

9. Proofreading;

10. Final report.

In our case, eight steps were followed. We did not include Step 6. Harmonization, since it is used for cross-cultural adaptations of the same instrument for multiple languages at the same time. Further, Step 7. Cognitive debriefing and Step 8. Review of cognitive debriefing results and finalization were unified in a single step named Understanding.

\section{TEST-RETEST RELIABILITY}

After producing the final Brazilian Portuguese version of FINDRISC (FINDRISC-Br), the test-retest reliability of the tool was assessed following Mokkink et al. ${ }^{21}$. To establish the test-retest reliability of FINDRISC-Br, the level of agreement between the test-retest responses of FINDRISC-Br was checked. The average interval between the first and second interviews was two weeks ${ }^{22,23}$. Cohen's kappa coefficients ${ }^{24}$ and intraclass correlation coefficients (ICC) ${ }^{25}$ and their $95 \%$ confidence intervals $(95 \% \mathrm{CI}$ ) were estimated. Both coefficients were calculated for each item of the FINDRISC questionnaire and further for the FINDRISC total score. We considered good reliability when kappa and ICC estimates were $>0.80$ and $>0.75$, respectively ${ }^{24,25}$. Statistical analysis was performed with the software package SAS 9.4 (SAS Institute, Inc., Cary, NC, USA).

\section{RESULTS}

\section{TRANSLATION AND CULTURAL ADAPTATION}

Figure 1 summarizes the different steps in the translation and cultural adaptation process of FINDRISC. 
Step 1 - Preparation

Agreement and consent from the authors to use the FINDRISC questionnaire

Step 2 - Forward Translation

Translation of FINDRISC from the original version in English into Brazilian Portuguese

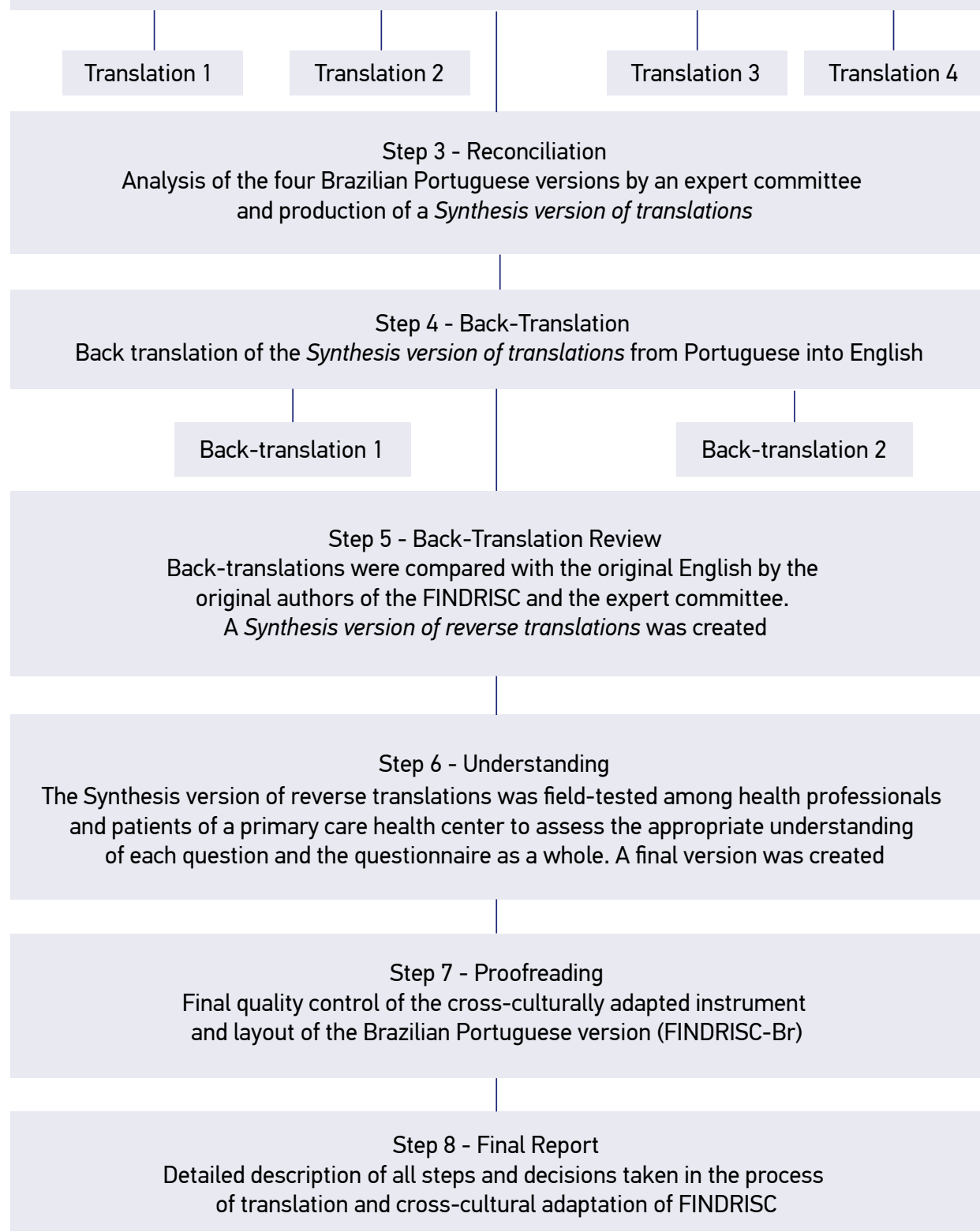

Figure 1. Flow diagram of the steps taken in the process of translation and cross-cultural adaptation of the Finnish Diabetes Risk Score (FINDRISC), according to the International Society for Pharmacoeconomics and Outcomes Research (ISPOR) guidelines. 


\section{Step 1: preparation}

Translation to Brazilian Portuguese of FINDRISC began after obtaining permission from the original authors, Dr. Jaana Lindström and Dr. Jaako Tuomilehto.

\section{Step 2: direct translation}

Four independent FINDRISC translations were obtained, from the original version in English into Brazilian Portuguese. Two versions were carried out by two professional bilingual translators whose first language was Brazilian Portuguese, fluent in English and resident in Brazil. A third version had been performed previously by some of the present authors, R.S.R. and J.A.M.C., who used it to screen hepatic steatosis ${ }^{13}$. The fourth version was produced by coauthor K.C.P.M., a registered dietician with experience in public health and fluent in English.

\section{Step 3: reconciliation}

An expert committee analyzed the four Brazilian Portuguese versions and produced a Synthesis Version of Translations adapting the terms to the culture of the target population. The expert committee was formed by three physicians and two registered dieticians with experience in public health or internal medicine, and also by one of the professional bilingual translators that participated in Step 2.

\section{Step 4: back translation}

The Synthesis Version of Translations was then back-translated into English by two other independent professional translators. Both translators were native English speakers and fluent in Brazilian Portuguese with no previous knowledge of the original version of FINDRISC in English.

\section{Step 5: back-translation review}

The authors of FINDRISC and the expert committee compared both back-translations with the original English version, looking for discrepancies. In this process, the semantic, idiomatic, experiential, and conceptual equivalences between versions were assessed ${ }^{26}$, and a Synthesis version of reverse translations was created. 


\section{Step 6: understanding}

The Synthesis version of reverse translations was field-tested on 17 health professionals (physicians, dieticians, nurses, and nursing technicians) and 15 subjects from the same primary care health center to check whether every question and the questionnaire as a whole were adequately understood. A Likert-type scale was used with the guiding question 'Do you understand what was asked?'. Scores ranged from 0 ('I did not understand anything') to 5 ('I understood perfectly and have no doubts'). Values $\geq 3$ were taken as an indication of satisfactory comprehension ${ }^{27}$. The interviewer simply read each item and recorded its score. Results showed $100 \%$ comprehension of FINDRISC-Br by health professionals and subjects alike. No adjustments being needed, this Brazilian Portuguese version became final.

\section{Step 7: proofreading}

Final review of FINDRISC's translation and cross-cultural adaptation was carried out. The text of FINDRISC-Br was formatted and minor spelling and grammatical errors corrected. Further to this, the permission was asked from the Finnish Diabetes Association to use their layout of the FINDRISC questionnaire, which was adopted for FINDRISC-Br (Figure 2).

\section{Step 8: final report}

Detailed description of all steps and decisions taken as part of the translation and cross-cultural adaptation process for FINDRISC, thus recording the development of the whole process.

\section{ASSESSMENT OF TEST-RETEST RELIABILITY}

A non-random sample of 105 people from the primary care health center was initially enrolled to assess test-retest reliability. Twenty-two of them missed the two-week evaluation (retest), resulting in 83 individuals with test and retest. Reasons for missing retest were: health problems $(\mathrm{n}=4)$, occupational commitments $(\mathrm{n}=2)$, refusals $(\mathrm{n}=3)$, and failure to reach the participant $(\mathrm{n}=13)$. No statistical differences were found in baseline FINDRISC-Br scores between participants and non-participants in the re-examination (chi-square test, $\mathrm{p}>0.05$ ). A descriptive analysis of the first interviews $(\mathrm{n}=83)$ is presented in Table 1 . The sample was mainly composed by women $(74.7 \%)$, mean age of 52.3 years (standard deviation $=16.4$ years). Almost $40 \%$ of subjects scored $\geq 15$ on the FINDRISC-Br questionnaire (Table 1).

The test and retest agreement levels are shown in Table 2. Although some items of the questionnaire presented coefficients lower than 0.8 , the questionnaire as a whole presented high reliability (Cohen's kappa $=0.82,95 \%$ CI $0.72-0.92$ and ICC $=0.94,95 \%$ CI $0.91-0.96$ ). 


\section{FORMULÁRIO DE AVALIAÇ̃̃O DE RISCO DE DIABETES TIPO 2 (ESCALA FINDRISC)}

Marque com " $X$ " a resposta adequada e some seus pontos

1. Idade

( ) Abaixo de 45 anos (0 ponto)

( ) 45 a 54 anos ( 2 pontos)

( ) 55 a 64 anos ( 3 pontos)

( ) Acima de 64 anos (4 pontos)

2. Índice de massa corporal

( ) Abaixo de $25 \mathrm{~kg} / \mathrm{m}^{2}$ (0 ponto)

( ) 25 a $30 \mathrm{~kg} / \mathrm{m}^{2}$ (1 ponto)

( ) Maior que $30 \mathrm{~kg} / \mathrm{m}^{2}$ (3 pontos)

3. Circunferência da cintura medida na altura do umbigo (figura)
HOMENS

( ) Menos de $94 \mathrm{~cm}$

( ) 94 a $102 \mathrm{~cm}$

() Mais de $102 \mathrm{~cm}$
MULHERES

( ) Menos de $80 \mathrm{~cm}$ (0 ponto) ( ) $80 \mathrm{a} 88 \mathrm{~cm}$ (3 pontos)

( ) Mais de $88 \mathrm{~cm}$ (4 pontos)

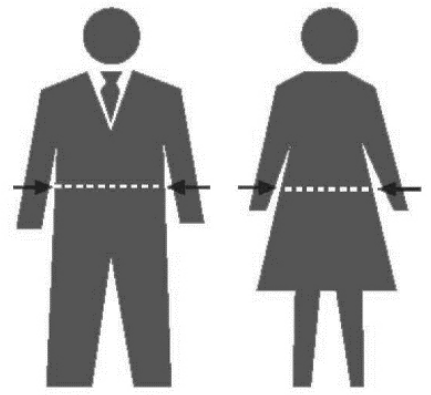

4. Pratica atividade física diariamente durante pelo menos, $\mathbf{3 0}$ minutos, no trabalho e/ou durante o tempo livre (incluindo as atividades da vida diária)?

( ) $\operatorname{Sim}(0$ ponto)

( ) Não (2 pontos)

5. Com que frequência come verduras, legumes e frutas?

( ) Todos os dias (0 ponto)

( ) Não como todos os dias (1 ponto)
6. Você toma regularmente ou já tomou medicação para pressão alta?

( ) Não (0 ponto)

( ) $\operatorname{Sim}(2$ pontos)

7. Você já apresentou glicemia (açúcar no sangue) elevada (ex. num exame de rotina, durante um problema de saúde ou durante a gravidez)?

( ) Não (0 ponto)

( ) $\operatorname{Sim}(5$ pontos)

8. Você tem alguém na família que foi diagnosticado com diabetes (do tipo 1 ou tipo 2)?

( ) Não (0 ponto)

( ) Sim: avós, tia, tio, primos de primeiro grau (mas não os pais, irmãos ou filhos) (3 pontos)

( ) Sim pais, imãos ou filhos (5 pontos)

\section{Pontuação total}

O risco de desenvolver diabetes tipo 2 , nos próximos 10 anos, é:

Menor que 7 RISCO BAIXO; estima-se que 1 em cada pontos 100 individuos irá desenvolver a doença

7 a 11 pontos RISCO DISCRETAMENTE AUMENTADO; estima-se que 1 em cada 25 individuos irá desenvolver a doença

12 a 14 pontos RISCO MODERADO; estima-se que $1 \mathrm{em}$ cada 6 individuos irá desenvolver a doença 15 a 20 pontos RISCO ALTO; estima-se que 1 em cada 3 indivíduos irá desenvolver a doença

Maior que RISCOMUITO ALTO; estima-se que $1 \mathrm{em}$ 20 pontos cada 2 indivíduos irá desenvolver a doença

Figure 2. Brazilian version of Finnish Diabetes Risk Score (FINDRISC) questionnaire. 
Table 1. Characteristics of subjects included test-retest reliability $(n=83)$.

Variable

$\mathrm{N}$

$\%$

Gender

\begin{tabular}{|l|l|l|}
\hline Male & 21 & 25.30 \\
\hline Female & 62 & 74.70 \\
\hline
\end{tabular}

Age group (years)

$<45$
$45-54$
$55-64$
$>64$

Body-mass index $\left(\mathrm{kg} / \mathrm{m}^{2}\right)$

\begin{tabular}{l|l|l}
\hline$<25$ & 17 & 20.48 \\
\hline $25-30$ & 34 & 40.96 \\
\hline$>30$ & 32 & 38.55 \\
\hline Waist circumference $(\mathrm{cm})$ & & \\
\hline Man $<94$, woman $<80$ & 10 & 12.05 \\
\hline Man 94-102, woman 80-88 & 15 & 18.07 \\
\hline Man $>102$, woman $>88$ & 58 & 69.88 \\
\hline
\end{tabular}

Physical activity $\geq 30 \mathrm{~min} /$ day

\begin{tabular}{|l|l|l}
\hline Yes & 59 & 71.08 \\
\hline No & 24 & 28.92 \\
\hline
\end{tabular}

Daily consumption of fruit and vegetables

\begin{tabular}{|l|l|l}
\hline Every day & 66 & 79.52 \\
\hline Not every day & 17 & 20.48 \\
\hline \begin{tabular}{l|l} 
Personal history of use of antihypertensive drugs \\
\hline No
\end{tabular} & 44 & 53.01 \\
\hline Yes & 39 & 46.99 \\
\hline Personal history of hyperglycemia & 67 & 80.72 \\
\hline No & 16 & 19.28 \\
\hline Yes & & \\
\hline
\end{tabular}

Family history of diabetes

\begin{tabular}{|l|l|l}
\hline No & 31 & 37.35 \\
\hline Yes: grandparent, aunt, uncle or first cousin & 15 & 18.07 \\
\hline Yes: parent, brother, sister or own child & 37 & 44.58 \\
\hline
\end{tabular}

FINDRISC score

\begin{tabular}{l|c|c}
\hline$<7$ & 12 & 14.46 \\
\hline $7-11$ & 22 & 26.51 \\
\hline $12-14$ & 16 & 19.28 \\
\hline $15-20$ & 29 & 34.94 \\
\hline$>20$ & 4 & 4.81 \\
\hline
\end{tabular}

FINDRISC: Finnish Diabetes Risk Score. 


\section{DISCUSSION}

This paper provides the first official Brazilian Portuguese version of FINDRISC in alignment with ISPOR guidelines. In the past, translation and cross-cultural adaptation of such tools amounted to be a simple translation or, at best, performing comparisons between the original tool and its back-translation ${ }^{28}$. The ISPOR guidelines were developed to reduce the heterogeneity of methods. These guidelines have been used extensively to translate and adapt health questionnaires in Brazil ${ }^{29-32}$ and across the world ${ }^{33,34}$.

The present translation and cultural adaptation of FINDRISC took place without unexpected difficulties. Question number 5, which refers to the consumption of fruits, vegetables, and berries in the original version, needed to be adapted and the term "berries" was dropped in line with Brazilian culture and commonly available varieties of food in the country. The assessment of test-retest reliability of FINDRISC-Br showed Cohen's kappa and ICC values higher than 0.8 for the questionnaire as a whole, showing adequate reliability. However, the level of agreement was below 0.8 for two questions: physical activity and consumption of fruits and vegetables. We believe that these two questions were those most sensitive in the questionnaire since participants might have changed their answer at retest due to social desirability bias. This bias, well known in epidemiology, regards participants either denying undesirable characteristics or attributing themselves desirable characteristics ${ }^{35}$.

The FINDRISC questionnaire was originally developed as a tool to predict T2DM in Finland ${ }^{1}$. Nowadays it is used around the world ${ }^{3,8,36}$, being easy to use, quick to apply, non-invasive, and low-cost. FINDRISC has also become useful to screen T2DM in populations previously not known to have T2DM ${ }^{11,12}$. FINDRISC-Br could be used in Brazil in, either way,

Table 2. Test-retest agreement levels for the Brazilian version of the Finnish Diabetes Risk Score (FINDRISC-Br) items in terms of Cohen's kappa coefficients and intraclass correlation coefficients (ICC) with the corresponding $95 \%$ confidence intervals $(95 \% \mathrm{Cl})$.

\begin{tabular}{|l|c|c|}
\hline FINDRISC variables & Kappa $(95 \% \mathrm{Cl})$ & ICC $(95 \% \mathrm{Cl})$ \\
\hline Age (years) & $0.97(0.92-1.00)$ & $0.96(0.94-0.98)$ \\
\hline Body-mass index $\left(\mathrm{kg} / \mathrm{m}^{2}\right)$ & $0.92(0.85-0.99)$ & $0.96(0.93-0.97)$ \\
\hline Waist circumference $(\mathrm{cm})$ & $0.93(0.86-0.99)$ & $0.95(0.93-0.97)$ \\
\hline Physical activity $\geq 30 \mathrm{~min} /$ day & $0.79(0.64-0.94)$ & $0.79(0.69-0.86)$ \\
\hline Daily consumption of fruit and vegetables & $0.63(0.41-0.84)$ & $0.63(0.48-0.74)$ \\
\hline Personal history of use of antihypertensive drugs & $0.93(0.85-1.00)$ & $0.93(0.89-0.95)$ \\
\hline Personal history of hyperglycemia & $0.96(0.88-1.00)$ & $0.96(0.94-0.98)$ \\
\hline Family history of diabetes & $0.87(0.77-0.96)$ & $0.88(0.82-0.92)$ \\
\hline FINDRISC total score & $0.82(0.72-0.92)$ & $0.94(0.91-0.96)$
\end{tabular}


to predict T2DM prospectively and to screen for previously undiagnosed T2DM. T2DM is a public health problem in Brazil, where almost half of people with diabetes are unaware of their condition ${ }^{37}$. Since T2DM is mostly asymptomatic during the first years of the disease onset, screening with a simple and inexpensive tool such as FINDRISC-Br is warranted.

This study may present some limitations. First, we did not validate FINDRISC-Br and therefore do not know yet the cut-off values for our population. Second, we used a non-random sample, which could bias the scores we found.

\section{CONCLUSION}

FINDRISC was translated into Brazilian Portuguese and culturally adapted following standard procedures, thus producing FINDRISC-Br. Validation is still needed, but already in the meantime, we believe that FINDRISC-Br has good potential as a reliable screening tool in different Brazilian settings and applications.

\section{ACKNOWLEDGEMENTS}

Enna Bierganns from the Finnish Diabetes Association, and Ana Silvia Sartori Barraviera Seabra Ferreira from the Distance Education and Health Information Technologies Unit (NEAD-TIS), São Paulo State University (UNESP), Medical School, Botucatu, SP, Brazil.

\section{REFERENCES}

1. Lindström J, Tuomilehto J. The diabetes risk score: a practical tool to predict type 2 diabetes risk. Diabetes Care 2003; 26(3): 725-31. https://doi.org/10.2337/ diacare.26.3.725

2. Saaristo T, Peltonen M, Lindström J, Saarikoski L, Sundvall J, Eriksson JG, et al. Cross-sectional evaluation of the Finnish Diabetes Risk Score: a tool to identify undetected type 2 diabetes, abnormal glucose tolerance and metabolic syndrome. Diab Vasc Dis Res 2005; 2(2): 67-72. https: / / doi.org/10.3132/dvdr.2005.011

3. Saaristo T, Moilanen L, Korpi-Hyövälti E, Vanhala M, Saltevo J, Niskanen L, et al. Lifestyle intervention for prevention of type 2 diabetes in primary health care: one-year follow-up of the Finnish National Diabetes Prevention Program (FIN-D2D). Diabetes Care 2010; 33(10): 2146-51. https:// doi.org/10.2337/ dc10-0410
4. Laatikainen T, Dunbar JA, Chapman A, Kilkkinen A, Vartiainen E, Heistaro S, et al. Prevention of type 2 diabetes by lifestyle intervention in an Australian primary health care setting: Greater Green Triangle (GGT) Diabetes Prevention Project. BMC Public Health 2007; 7: 249. https: / / doi.org/10.1186/1471-2458-7-249

5. Lindström J, Peltonen M, Eriksson JG, Aunola S, Hämäläinen H, Ilanne-Parikka P, et al. Determinants for the effectiveness of lifestyle intervention in the Finnish Diabetes Prevention Study. Diabetes Care 2008; 31(5): 857-62. https: / / doi.org/10.2337/ dc07-2162

6. Schwarz PE, Gruhl U, Bornstein SR, Landgraf R, Hall M, Tuomilehto J. The European perspective on diabetes prevention: development and Implementation of A European Guideline and training standards for diabetes prevention (IMAGE). Diab Vasc Dis Res 2007; 4(4): 353-7. https:// doi.org/10.3132/dvdr.2007.064 
7. Schwarz PE, Lindström J, Kissimova-Scarbeck K, Szybinski Z, Barengo NC, Peltonen M, et al. The European perspective of type 2 diabetes prevention: diabetes in Europe--prevention using lifestyle, physical activity and nutritional intervention (DE-PLAN) project. Exp Clin Endocrinol Diabetes 2008; 116(3): 167-72. https: / / doi.org/10.1055/s-2007-992115

8. Zhang L, Zhang Z, Zhang Y, Hu G, Chen L. Evaluation of Finnish Diabetes Risk Score in screening undiagnosed diabetes and prediabetes among U.S. adults by gender and race: NHANES 1999-2010. PLoS One 2014; 9(5): e97865. https:// doi.org/10.1371/journal.pone.0097865

9. Tabák AG, Herder C, Rathmann W, Brunner EJ, Kivimäki M. Prediabetes: a high-risk state for diabetes development. Lancet 2012; 379(9833): 2279-90. https: / / dx.doi.org/10.1016\%2FS0140-6736(12)60283-9

10. Saleem SM, Khan SMS, JAN SS. Finnish Diabetic Risk Score: A Tool for Predicting Risk of Undiagnosed Type 2 Diabetes Mellitus. Ann Med Health Sci Rev 2017; 7: 295-8.

11. Gomez-Arbelaez D, Alvarado-Jurado L, Ayala-Castillo M, Forero-Naranjo L, Camacho PA, Lopez-Jaramillo P. Evaluation of the Finnish Diabetes Risk Score to predict type 2 diabetes mellitus in a Colombian population: A longitudinal observational study. World J Diabetes 2015; 6(17): 1337-44. https: / / dx.doi. org/10.4239\%2Fwjd.v6.i17.1337

12. Salinero-Fort MA, Burgos-Lunar C, Lahoz C, Mostaza JM, Abánades-Herranz JC, Laguna-Cuesta F, et al. Performance of the Finnish Diabetes Risk Score and a Simplified Finnish Diabetes Risk Score in a Community-Based, Cross-Sectional Programme for Screening of Undiagnosed Type 2 Diabetes Mellitus and Dysglycaemia in Madrid, Spain: The SPREDIA-2 Study. PLoS One 2016; 11(7): e0158489. https: / / doi. org/10.1371/journal.pone.0158489

13. CarvalhoJAM, Barengo NC, Tuomilehto J, Conceição RD, Santos RD. The Finnish Diabetes Risk Score (FINDRISC) as a screening tool for hepatic steatosis. Ann Med 2011; 43(6): 487-94. https:// doi.org/10.31 09/07853890.2011.554428

14. Silventoinen K, Pankow J, Lindström J, Jousilahti P, Hu G, Tuomilehto J. The validity of the Finnish Diabetes Risk Score for the prediction of the incidence of coronary heart disease and stroke, and total mortality. Eur J Cardiovasc Prev Rehabil 2005; 12(5): 451-8. https:/ / doi.org/10.1097/01.hjr.0000174793.31812.21

15. Fizelova M, Jauhiainen R, Stančáková A, Kuusisto J, Laakso M. Finnish Diabetes Risk Score Is Associated with Impaired Insulin Secretion and Insulin Sensitivity, Drug-Treated Hypertension and Cardiovascular Disease: A Follow-Up Study of the METSIM Cohort. PLoS One 2016; 11(11): e0166584. https://doi. org/10.1371/journal.pone.0166584
16. Barros CR, Cezaretto A, Salvador EP, Santos TC, Siqueira-Catania A, Ferreira SRG. Implementação de programa estruturado de hábitos de vida saudáveis para redução de risco cardiometabólico. Arq Bras Endocrinol Metab 2013; 57(1): 7-18. https://doi. org/10.1590/S0004-27302013000100002

17. Marinho NBP, Vasconcelos HCA, Alencar AMPG, Almeida PC, Damasceno MMC. Risco para diabetes mellitus tipo 2 e fatores associados. Acta Paul Enferm 2013; 26(6): 569-74. https:// doi.org/10.1590/ S0103-21002013000600010

18. Bittencourt A, Vinholes DB. Estimativa do risco para diabetes mellitus tipo 2 em bancários da cidade de Tubarão, estado de Santa Catarina, Brasil. Sci Med (Porto Alegre) 2013; 23(2): 82-9.

19. Araújo LO, Silva ES, Mariano JO, Moreira RC, Prezotto KH, Fernandes CAM, et al. Risco para desenvolvimento do diabetes mellitus em usuários da atenção primária a saúde: um estudo transversal. Rev Gaúcha Enferm 2015; 36(4): 77-83. https: / / doi. org/10.1590/1983-1447.2015.04.50195

20. Wild D, Grove A, Martin M, Eremenco S, McElroy S, Verjee-Lorenz A, et al. Principles of Good Practice for the Translation and Cultural Adaptation Process for Patient-Reported Outcomes (PRO) Measures: report of the ISPOR Task Force for Translation and Cultural Adaptation. Value Health 2005; 8(2): 94-104. https: / / doi.org/10.1111/j.1524-4733.2005.04054.x

21. Mokkink LB, Terwee CB, Patrick DL, Alonso J, Stratford PW, Knol DL, et al. The COSMIN study reached international consensus on taxonomy, terminology, and definitions of measurement properties for health-related patient-reported outcomes. J Clin Epidemiol 2010; 63(7): 737-45. https: / / doi.org/10.1016/j.jclinepi.2010.02.006

22. Martins GA. Sobre Confiabilidade e Validade. Rev Bras Ges Neg 2006; 8(20): 1-12.

23. Terwee CB, Bot SD, de Boer MR, van der Windt DA, Knol DL, Dekker J, et al. Quality criteria were proposed for measurement properties of health status questionnaires. J Clin Epidemiol 2007; 60(1): 34-42. https: / / doi.org/10.1016/j.jclinepi.2006.03.012

24. Landis JR, Koch GG. The measurement of observer agreement for categorical data. Biometrics 1977; 33(1): 159-74.

25. Koo TK, Li MY. A Guideline of Selecting and Reporting Intraclass Correlation Coefficients for Reliability Research. J Chiropr Med 2016; 15(2): 155-63. https: / / doi.org/10.1016/j.jcm.2016.02.012

26. Beaton DE, Bombardier C, Guillemin F, Ferraz MB. Guidelines for the process of cross-cultural adaptation of self-report measures. Spine (Phila Pa 1976) 2000; 25(24): 3186-91. https://doi. org/10.1097/00007632-200012150-00014 
27. Dalmoro M, Vieira KM. Dilemas na construção de escalas tipo Likert: o número de itens e a disposição influenciam nos resultados? RGO 2013; 6(3): 161-74. http: / / dx.doi.org/10.22277/rgo.v6i3.1386

28. Reichenheim ME, Moraes CL. [Operationalizing the cross-cultural adaptation of epidemiological measurement instruments]. Rev Saúde Pública 2007; 41(4): 665-73. https:// doi.org/10.1590/ S0034-89102006005000035

29. Baeza FLC, Caldieraro MAK, Pinheiro DO, Fleck MP. Translation and cross-cultural adaptation into Brazilian Portuguese of the Measure of Parental Style (MOPS) - a self-reported scale - according to the International Society for Pharmacoeconomics and Outcomes Research (ISPOR) recommendations. Rev Bras Psiquiatr 2010; 32(2): 159-63. https://doi.org/10.1590/ S1516-44462010000200011

30. Spanemberg L, Parker G, Caldieraro MA, Vares EA, Costa F, Costa MM, et al. Translation and cross-cultural adaptation of the Temperament \& Personality Questionnaire into Brazilian Portuguese. Trends Psychiatry Psychother 2014; 36(4): 214-8. https://doi. org/10.1590/2237-6089-2014-1007

31. Fonseca LBM, Silveira EA, Lima NM, Rabahi MF. Tradução e adaptação transcultural do questionário STOP-Bang para a língua portuguesa falada no Brasil. J Bras Pneumol 2016; 42(4): 266-72. https:// doi. org/10.1590/s1806-37562015000000243

32. Mondrzak R, Reinert C, Sandri A, Spanemberg L, Nogueira EL, Bertoluci M, et al. Translation and cross-cultural adaptation of the Rating Scale for Countertransference (RSCT) to American English. Trends Psychiatry Psychother 2016; 38(4): 221-6. https: / / doi.org/10.1590/2237-6089-2015-0078
33. Hidalgo Ovejero AM, Menéndez García M, Bermejo Fraile B, García Mata S, Forcén Alonso T, Mateo Sebastián P. Cross-cultural adaptation of the Zurich Claudication Questionnaire. Validation study of the Spanish version. An Sist Sanit Navar 2015; 38(1): 41-52. https: / / doi.org/ 10.23938/ASSN.0052

34. Hägi-Pedersen D, Thybo KH, Holgersen TH, Jensen JJ, Gaudreau JD, Radtke FM. Nu-DESC DK: the Danish version of the nursing delirium screening scale (nu-DESC). BMC Nurs 2017; 16: 75. https:// doi.org/10.1186/s12912-017-0271-x

35. Krumpal, I. Determinants of social desirability bias in sensitive surveys: a literature review. Qual Quant 2013; 47: 2025-47. https://doi.org/10.1007/s11135-011-9640-9

36. Meijnikman AS, De Block CEM, Verrijken A, Mertens I, Van Gaal LF. Predicting type 2 diabetes mellitus: a comparison between the FINDRISC score and the metabolic syndrome. Diabetol Metab Syndr 2018; 10 : 12. https: / / dx.doi.org/10.1186\%2Fs13098-018-0310-0 37. Bertoldi AD, Kanavos P, França GV, Carraro A, Tejada CA, Hallal PC, et al. Epidemiology, management, complications and costs associated with type 2 diabetes in Brazil: a comprehensive literature review. Global Health 2013; 9: 62. https:// doi.org/10.1186/1744-8603-9-62

\section{Received on: 04/26/2019 \\ Revised on: 10/03/2019 \\ Accepted on: 10/16/2019}

\author{
Author's contributions: E.M. Barim, K. C. P.McLellan, and \\ C. Murta-Nascimento participated in the conception and \\ design of the work, data collection, and drafting the \\ manuscript; R. S. Ribeiro, J. A. Maluf de Carvalho, \\ J. Lindström, andJ. Tuomilehto participated in data collection; \\ J. E. Corrente participated in data analysis. All authors \\ discussed the results and commented on the manuscript.
}

